\title{
Influences of Date of Sowing on Yield Attributes and Yield of Linseed (Linum usitatissimum L.) Varieties under Dryland Condition in Eastern Uttar Pradesh
}

\author{
Avinash Chandra Maurya ${ }^{1}$, M. Raghuveer ${ }^{1 *}$, Gargi Goswami ${ }^{1}$ and Santosh Kumar ${ }^{2}$ \\ ${ }^{1}$ Department of Agronomy, Institute of Agricultural Sciences, Banaras Hindu University, \\ Varanasi, 221005, India \\ ${ }^{2}$ Department of Agronomy, Regional Research Station, Agwanpur, Bihar Agricultural \\ University, Sabour, 813210, India \\ *Corresponding author
}

\section{A B S T R A C T}

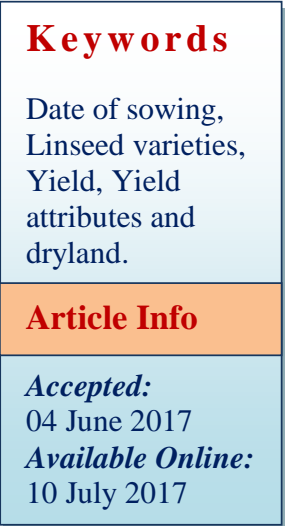

A field experiment was conducted during rabi seasons of 2011-12 to study the Influence of date of sowing on yield attributes and yield of linseed (Linum usitatissimum L.) varieties under dryland condition in Eastern Uttar Pradesh at Agricultural research farm, Institute of Agricultural Sciences, Varanasi, Uttar Pradesh, India. Crop sown on 4 November which was significantly superior over both November 11 and 18 sown crop while significant difference among the cultivars (Shekhar, Neelam and T-397) also found in yield attributes (number of capsule plant ${ }^{-1}$, number of seed capsule $^{-1}$ and test weight,) and yield (Grain yield $\mathrm{q} \mathrm{ha}^{-1}$, Straw yield $\mathrm{t} \mathrm{ha}{ }^{-1}$ and Harvest Index \%).

\section{Introduction}

India ranks first in terms of area under linseed cultivation and third in production in world. In India, linseed cultivated about 4.68 lakh ha and total linseed production is 1.63 lakh tones (Anonymous, 2012). In many regions farmers fail to undertake timely sowing which results to shorter growth period available to late sown linseed coupled with high temperature and hot winds during reproductive growth period, which leads to forced maturity and ultimately poor grain yield. The sowing date was a very important management tool in minimizing the negative impact of high temperature and moisture stress during the critical flowering and seed filling periods (Chauhan et al., 2008). Among the different oilseeds crops grown in country, linseed is considered the most important industrial oilseed crop of India. It is grown either for oil extracted from seed or for fibre from stem. Seed contain oil ranging from 37 to $43 \%$. Every part of linseed plant is utilized commercially either directly or after processing most of oil is used in the industry for manufacture of paints, varnishes, inks, soap and very small fraction of it is used for edible purpose. There has been a continuous decline in linseed area in the country during 
the last four decades so to sustain linseed production mainly in rainfed area. To obtain higher crop yield evaluate suitable agro technique for different agro climatic zone like optimum sowing time, proper management of soil, soil nutrient and soil moisture to produce higher crop yield in dry land condition are the major research threats for agronomic research worker (Mohammada, 2012).

\section{Materials and Methods}

The present investigation was carried out during rabi season of 2011-2012 at Agriculture research farm, Banaras Hindu University, Varanasi. It is evident from soil analysis that soil of the experimental field was sandy clay loam category $\mathrm{pH} 7.2$ and low in available nitrogen $\left(201 \mathrm{~kg} \mathrm{ha}^{-1}\right)$, medium in available phosphorus (15.37 $\left.\mathrm{kg} \mathrm{ha}^{-1}\right)$ and potassium status $\left(172 \mathrm{~kg} \mathrm{ha}^{-1}\right)$. The maximum and minimum temperatures during crop growth period ranged between 37.2 and $7.2^{0} \mathrm{C}$, respectively, with relative humidity in the range of 22 to $80.0 \%$ during 2011-12. The experiment comprised three date of sowing (04-11-2011, 11-11-2011 and 18-11-2011) and three varieties (Shekhar, Neelam and T397) and was laid out in split plot design and replicated thrice. The recommended fertilizer dose was $50 \mathrm{~kg} \mathrm{~N}: 50 \mathrm{~kg} \mathrm{P}_{2} \mathrm{O}_{5}: 50 \mathrm{~kg} \mathrm{~K}_{2} \mathrm{O} \mathrm{ha}^{-1}$ supplied through urea, single super phosphate and muriate of potash, respectively. The linseed was sown manually in rows at $4-5 \mathrm{~cm}$ depth using $30 \mathrm{~kg} \mathrm{ha}^{-1}$ seed rate with $30 \mathrm{~cm}$ row spacing. All the recommended package of practices was adopted same in all the treatments during the crop growth periods. All biometric observation was recorded with tagged plant except dry weight where plant was uprooted carefully and average dry weight plant $^{-1}$ was recorded. All observation on yield attributes (number of capsule plant ${ }^{-1}$, number of seed capsule ${ }^{-1}$ and test weight) and yield (Grain yield $\mathrm{q} \mathrm{ha}{ }^{-1}$, Straw yield $\mathrm{t} \mathrm{ha}{ }^{-1}$ and Harvest Index) were recorded from the marked area of net plot at harvest. Grain and straw yield were recorded on per plot basis and then converted to $\mathrm{kg} \mathrm{ha}^{-1}$. The yield of linseed was converted into gross return in rupees $\mathrm{ha}^{-1}$ based on current price prevailing in the market and approved for the sale of product at research farm of the Institute. All the data obtained from the experiment were put to statistical analysis by adopting appropriate method of "Analysis of Variance" as suggested by the Gomez and Gomez (1976). Critical difference (CD) at 5\% level of significance was worked out to determine the difference between treatments.

\section{Results and Discussion}

\section{Number of capsules plant ${ }^{-1}$}

The data pertaining to number of capsule at maturity (Table 1) was affected by different treatments. The maximum number of capsule plant $^{-1}$ was recorded in crop sown on 4 November (38.68) which were significantly superior to both 11 and 18 November sown crops. The crop sown on 18 November produced significantly less number of number of capsule than 11 November sown crop, respectively. In case of varieties did differ significantly for number of capsule plant $^{-1}$ however, highest number of capsule plant $^{-1}$ was recorded in Shekhar and followed by Neelam while that T 397 was significantly less over the rest of treatments. The scrutiny of data of number of capsules plant ${ }^{-1}$ indicated that the crop sown on 4 November recorded the highest number of capsules plant ${ }^{-1}$. The interesting behaviour exhibited the fact that first planted crop was exposed to favourable weather during the whole life cycle and thus the different phases of plant life was completed at appropriate timings, which resulted in production of more number of branches plant ${ }^{-1}$ and ultimately more number of capsules plant ${ }^{-1}$. The subsequent planted crops (11 and 18 November) could not enjoy 
the advantages of favourable weather conditions available for the initially planted date. Similar responses were recorded by Mohammada (2012).

\section{Seed capsule ${ }^{-1}$}

The data recorded on number of seed capsule ${ }^{-1}$ exhibited increase trend with delayed sowing. The maximum number of seed capsule ${ }^{-1}$ was obtained in 18 November sowing which was significantly higher than both the crops sown on 11 and 4 November. However, the crops sown on 11 and 4 November was differed significantly to each other. The difference in number of seed capsule ${ }^{-1}$ among varieties was found significant. However, significantly highest number of seed capsule ${ }^{-1}$ was observed in Shekhar followed by Neelam and T 397, respectively. Number of Seed capsule ${ }^{-1}$ significantly influenced by sowing time and it gradually increased as sowing was delayed. Because, it is influenced by environmental factor that of temperature prevailed during the time of sowing and vegetative and reproductive stages. In 4 November sown crop the number of Seed capsule ${ }^{-1}$ was quite less but of good weight, which positively contributed to high yield. High temperature during the later part of the reproductive stage of 18 November sowing caused forced maturity of the crop resulting in development of more number of seed capsule ${ }^{-1}$ which were small, shrivelled and of low weight as evident from its low test weight. Similar responses were recorded by Yadav et al., (2005).

\section{Test weight (g)}

The data showed significant difference in test weight significantly decreased with delay in sowing. It was highest in the crop sown on 4 November which was significantly higher than 11 November and 18 November sowing, respectively. In case of varieties the highest test weight was recorded in Shekhar followed by Neelam, and T 397 was significantly lower over the rest of the treatment. This is influenced by environment particularly that of temperature prevailed during the time of vegetative and reproductive stages. Test weight was significantly influenced by dates of sowing, it was highest in the crop sown on 4 November and decreased as sowing was delayed. This might be due to the fact that under later sown conditions the grains were forced to mature and dry because of sudden rise in temperature coupled with hot wind. Thus, the grains obtained from 18 November sown crop were small and shrivelled and ultimately resulted in lower test weight. On the other hand, the timely sown crop gets an advantage because after having completed its vegetative growth satisfactory it comes in the capsuleing stage when the temperature is quite favourable. Kalita et al., (2005) also reported similar findings and stated that timely sowing gave higher test weight as compared to delayed sowing.

\section{Grain and straw yield (q ha $\left.{ }^{-1}\right)$}

The data (Table 2) related to grain yield as affected by different treatments. All the dates of sowing differed significantly to each other in grain yield. The significantly highest grain yield was obtained in the crop sown on November 4 followed by November 11 and 18, respectively. The grain yield was significantly influenced by different varieties and all varieties were noticed significant difference to each other. In case of varieties the highest grain yield was produced by Shekhar followed by Neelam and T 397, respectively. While in case of straw yield significantly affected by sowing time of the crop. The highest straw yield was recorded in the crop sown on 4 November followed by the crop sown on 11 November and both were significantly superior to the crop sown on 18 November while difference in straw yield of varieties was significant maximum straw 
yield was recorded in Shekhar followed by Neelam and T 397, respectively. Grain yield decreased significantly as sowing was delayed from 4 November. This might be due to cumulative effect of poor expression of vegetative growth and yield contributing characters i.e. number of capsules plant ${ }^{-1}$, seed capsule ${ }^{-1}$ and test weight under late sown conditions accompanied with high temperature and hot winds which leads toward forced maturity of the crop and ultimately resulted in lower grain yield. The early sown crop, on the other hand, having favourable cool weather conditions for longer duration recorded better growth and yield attributes resulted in greater productivity. Similar results have also been reported by Singh and Bohra (2006).

\section{Harvest index (\%)}

Harvest index was highest in the crop sown on 18 November followed by November 11 and 4 sown crops, respectively. Among varieties highest harvest index was recorded in T 397 followed by Neelam and Shekhar, respectively.

\section{Economics}

It is evident from the data (Table 3) that highest net return and benefit cost ratio was obtained in the crop sown on 4 November followed by the crop sown on 11 and B: C Ratio and 18 November and B: C Ratio, respectively. But varieties also exhibited difference the highest net return and benefit cost ratio was obtained in Shekhar followed by Neelam and B: C Ratio and T 397 and B: C Ratio, respectively.

Varieties exhibited differences in their economics and the highest net return and benefit cost ratio was obtained in Shekhar followed by Neelam and T 397, respectively. The lead of Shekhar was due to the highest grain yield production in comparison to other varieties. On the basis of the results of present investigation the following conclusion may be drawn that was sowing of linseed variety Shekhar on 4 November (first week of November) gave highest grain yield and benefit cost ratio.

Table.1 Effect of dates of sowing on number of capsule plant ${ }^{-1}$, number of grain capsule ${ }^{-1}$ and 1000 grain weight of linseed varieties

\begin{tabular}{lccc}
\hline Treatment & $\begin{array}{c}\text { Number of capsule } \\
\text { plant }^{-\mathbf{1}}\end{array}$ & $\begin{array}{c}\text { Number of grain } \\
\text { capsule }^{-\mathbf{1}}\end{array}$ & $\begin{array}{c}\text { Test weight (g) } \\
\text { (1000 grain) }\end{array}$ \\
\hline Date of Sowing & & & \\
04- November & 38.68 & 8.50 & 9.30 \\
11-November & 35.67 & 8.90 & 8.42 \\
18-November & 31.68 & 9.27 & 7.87 \\
CD (P=0.05) & 0.268 & 0.123 & 0.108 \\
Varieties & & & \\
Shekhar & 38.58 & 9.75 & 9.10 \\
Neelam & 36.19 & 8.79 & 8.46 \\
T - 397 & 31.25 & 8.13 & 8.03 \\
CD (P=0.05) & 0.337 & 0.084 & 0.038 \\
\hline
\end{tabular}


Table.2 Effect of Dates of Sowing on Grain yield, Straw yield and Harvest index of linseed varieties

\begin{tabular}{lccc}
\hline Treatment & $\begin{array}{c}\text { Grain Yield } \\
\left(\mathbf{q} \mathbf{~ h a}^{-\mathbf{1}}\right)\end{array}$ & $\begin{array}{c}\text { Straw Yield } \\
\left(\mathbf{q} \mathbf{~ h a}^{-\mathbf{1}}\right)\end{array}$ & $\begin{array}{c}\text { Harvest Index } \\
(\mathbf{\%})\end{array}$ \\
\hline Date of sowing & & & \\
04-November & 13.95 & 28.67 & 32.96 \\
11-November & 13.29 & 27.46 & 32.94 \\
18-November & 12.79 & 26.19 & 33.50 \\
CD (P=0.05) & 0.073 & 0.397 & 0.00 \\
Varieties & & & \\
Shekhar & 14.19 & 28.64 & 32.88 \\
Neelam & 13.43 & 27.37 & 32.93 \\
T - 397 & 12.40 & 26.31 & 33.60 \\
CD $(\mathrm{P}=0.05)$ & 0.085 & 0.387 & 0.00 \\
\hline
\end{tabular}

Table.3 Effect of dates of sowing on economics of linseed varieties

\begin{tabular}{|c|c|c|c|c|}
\hline Treatment & $\begin{array}{c}\text { Cost of } \\
\text { cultivation }\end{array}$ & $\begin{array}{c}\text { Gross return } \\
\left(\text { Rs. ha }{ }^{-1}\right)\end{array}$ & $\begin{array}{l}\text { Net return } \\
\left(\text { Rs. ha }{ }^{-1}\right)\end{array}$ & $\begin{array}{l}\text { Benefit cost } \\
\text { ratio }\end{array}$ \\
\hline \multicolumn{5}{|l|}{ Date of Sowing } \\
\hline 07-November & 17533.10 & 50438.33 & 32905.23 & 1.88 \\
\hline 11-November & 17533.10 & 48119.33 & 30586.23 & 1.74 \\
\hline 18-November & 17533.10 & 46221.67 & 28688.57 & 1.64 \\
\hline \multicolumn{5}{|l|}{ Varieties } \\
\hline Shekhar & 17533.10 & 51158.00 & 33624.90 & 1.92 \\
\hline Neelam & 17533.10 & 48513.67 & 30980.57 & 1.77 \\
\hline T - 397 & 17533.10 & 45107.67 & 27574.57 & 1.57 \\
\hline
\end{tabular}

\section{Number of capsules plant ${ }^{-1}$}

The interesting behaviour exhibited the fact that first planted crop was exposed to favourable weather during the whole life cycle and thus the different phases of plant life was completed at appropriate timings, which resulted in production of more number of branches plant ${ }^{-1}$ and ultimately more number of capsules plant ${ }^{-1}$.

The subsequent planted crops (11 and 18 November) could not enjoy the advantages of favourable weather conditions available for the initially planted date. Similar responses were recorded by Mohammada (2012).

\section{Seed capsule ${ }^{-1}$}

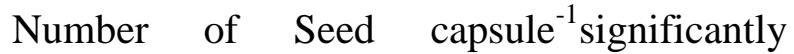
influenced by sowing time and it gradually increased as sowing was delayed. Because, it is influenced by environmental factor that of temperature prevailed during the time of sowing and vegetative and reproductive stages.

In 4 November sown crop the number of Seed capsule $^{-1}$ was quite less but of good weight, which positively contributed to high yield. High temperature during the later part of the reproductive stage of 18 November sowing caused forced maturity of the crop resulting in development of more number of seed capsule 
1 which were small, shrivelled and of low weight as evident from its low test weight. Similar responses were recorded by Yadav et al., (2005).

\section{Test weight (g)}

This is influenced by environment particularly that of temperature prevailed during the time of vegetative and reproductive stages. Test weight was significantly influenced by dates of sowing, it was highest in the crop sown on 4 November and decreased as sowing was delayed.

This might be due to the fact that under later sown conditions the grains were forced to mature and dry because of sudden rise in temperature coupled with hot wind. Thus, the grains obtained from 18 November sown crop were small and shrivelled and ultimately resulted in lower test weight. On the other hand, the timely sown crop gets an advantage because after having completed its vegetative growth satisfactory it comes in the capsuleing stage when the temperature is quite favourable. Kalita et al., (2005) also reported similar findings and stated that timely sowing gave higher test weight as compared to delayed sowing.

\section{Grain and straw yield $\left(\mathbf{q} \mathbf{h a}^{-1}\right)$}

Grain yield decreased significantly as sowing was delayed from 4 November. This might be due to cumulative effect of poor expression of vegetative growth and yield contributing characters i.e. number of capsules plant ${ }^{-1}$, seed capsule ${ }^{-1}$ and test weight under late sown conditions accompanied with high temperature and hot winds which leads toward forced maturity of the crop and ultimately resulted in lower grain yield. The early sown crop, on the other hand, having favourable cool weather conditions for longer duration recorded better growth and yield attributes resulted in greater productivity. Similar results have also been reported by Singh and Bohra (2006).

\section{Harvest index (\%)}

This might be due to maximum obtained both grain and straw yields of crop at timely sowing and which helped crop to sync with environment.

\section{Economics}

The lead of Shekhar was due to the highest grain yield production in comparison to other varieties.

On the basis of the results of present investigation the following conclusion may be drawn that was sowing of linseed variety Shekhar on 4 November (first week of November) gave highest grain yield and benefit cost ratio.

\section{References}

Anonymous, 2012. Economic survey of India, Economic Division Ministry of Finance Govt. of India.

Chauhan, D. V. S., M. D. Lodhi and Verma, N. K. 2008. Effect of sowing dates, varieties and number of irrigations on yield attributes, yield and quality of linseed under Bundelkhand condition of Uttar Pradesh. Agricultural Science Digest 28(4): 271-273.

Kalita, H. P, C. Bora and Debnath, M. C. 2005. Effect of sowing date and tillage practices on the growth and yield of rabi crops grown in medium winter ricelands under rainfed conditions. Crop Research (Hisar) 30(2): 139-142.

Lisson, S. N. and Mendham, N. J. 2000. Agronomic studies of flax in southeastern Australia. Australian Journal of Experimental Agriculture 40(8): 1101- 
1112.

Saeidi, G. 2008. Genetic variation and heritability for germination, seed vigour and field emergence in brown and yellow-seeded genotypes of flax. International Journal of Plant Production 2(1): 15-22.

Shaikh, F. G., D. N. Gokhale, B. S. Rokade and Jadhav. P. J. 2009. Effect of sowing date on some growth characters in linseed. Journal of Agrometeorology 11(2): 203-205.

Singh, V. K., T. Singh and Bohra, J. S. 2006. Comparative performance of sulphur, seed rate and date of sowing on yield, quality and nutrient uptake by linseed under rainfed conditions of Varanasi region. Crop Research (Hisar) 31(1): 63-65.

Yadav, R. A., O. P. Mathuria and Singh. D. 2006. Studies on date of sowing and seed rate of double-purpose linseed. Plant Archives 5(2): 503-507.

Zubal, P. 2001. The effects of sowing date, seeding rate and nutrition on yields of the oilseed flax cultivars. Vedecke Prace Vyskumneho Ustavu Rastlinnej Vyroby Piest'any 30: 33-38.

\section{How to cite this article:}

Avinash Chandra Maurya, M. Raghuveer, Gargi Goswami and Santosh Kumar. 2017. Influences of Date of Sowing on Yield Attributes and Yield of Linseed (Linum usitatissimum L.) Varieties under Dryland Condition in Eastern Uttar Pradesh. Int.J.Curr.Microbiol.App.Sci. 6(7): 481-487. doi: https://doi.org/10.20546/ijcmas.2017.607.057 